\title{
Butterfly diversity and biogeography on the Croatian karst mountain Biokovo: Vertical distribution and preference for altitude and aspect?
}

\author{
Iva MIHOCI ${ }^{1}$, Vladimir HRŠAK ${ }^{2}$, Mladen KUČINIĆ ${ }^{3}$, VlatKa MiČETIĆ STANKOVIĆ ${ }^{3}$, Antun DELIĆ ${ }^{4}$ \\ and NIKOLA TVRTKOVIĆ ${ }^{1}$
${ }^{1}$ Croatian Natural History Museum, Department of Zoology, Demetrova 1, 10000 Zagreb, Croatia; e-mails: iva.mihoci@hpm.hr, nikola.tvrtkovic@hpm.hr
${ }^{2}$ University of Zagreb, Faculty of Science, Department of Biology, Maruli ćev Trg 20/II, 10000 Zagreb, Croatia; e-mail:vhrsak@lipa.botanic.hr \\ ${ }^{3}$ University of Zagreb, Faculty of Science, Department of Biology, Group of Systematic Zoology \& Entomology, Rooseveltov trg 6, \\ 10000 Zagreb, Croatia; e-mails: kucinic@zg.biol.pmf.hr, vmicetic@zg.biol.pmf.hr \\ ${ }^{4}$ Faculty of Education, Savska cesta 77, 10000 Zagreb, Croatia; e-mail: a_delic@yahoo.com
}

Key words. Lepidoptera, butterflies, Dinaric karst, aspect, altitude, indicators

\begin{abstract}
Geographic isolation, altitude, climate, landscape and habitat are significant predictors of butterfly diversity in mountain ecosystems. Their diversity and its dependence on altitude, aspect (compass bearing) and biogeographic characteristics of the butterflies were surveyed on the karst mountain Biokovo in southern Croatia. The results affirm that there is a high diversity of butterflies in the study area and the species composition and biogeographic elements are more dependent on altitude than aspect of the mountain. The present study indicates that climate, relief and habitat preferences strongly influence the biogeographic features of species and the relationship between species richness per site and altitude, aspect and the altitude-aspect interaction.
\end{abstract}

\section{INTRODUCTION}

Butterflies are well known taxonomically and ecologically (Kudrna, 1986; Kristensen et al., 2007). Their diversity and geographic patterns, vertical distribution, variation in species richness with altitude and species response to changing altitude, have been a major concern of many researchers interested in mountain biogeography (e.g. Gutiérrez, 1997; Liška \& Skyva, 1997; Wettstein \& Schmid, 1999; Beneš et al., 2000; Varga, 2003a, b, 2008). Species diversity varies spatially, displaying latitudinal and longitudinal gradients and there are core areas that serve as centres of dispersal and restricted territories where endemic species accumulate (Varga, 1995; Varga \& Schmitt, 2008).

In mountain ecosystems, the distribution of species is determined by the suitability of habitat and climate (Storch et al., 2003). The main factors that influence species distribution and diversity include geographic isolation, altitude, climate and features of landscape and habitat such as structure, heterogeneity and quality (e.g. Kudrna, 1986; Fleishman et al., 1998, 2003; Wettstein \& Schmid, 1999; Pyrcz \& Wojtusiak, 2002; Storch et al., 2003).

Mountain ecosystems, though considered "simple" because the number of species decreases with altitude, are extremely heterogeneous (Haslett, 1997a). The diversity and area/size of habitats at different altitudes affects spatial distribution, species richness, morphology, physiology, life cycle and behavioural patterns (Haslett, 1997b).

Research on the diversity of butterflies occurring on the karst mountain range Biokovo (Dalmatia, southern Croa- tia) has continued, off and on, since the $19^{\text {th }}$ century (Mann, 1869; Stauder, 1923; Sijarić, 1991a, b; Mihoci \& Šašić, 2005). This mountain is a part of the Dinaric karst, which is a mountain range approximately $700 \mathrm{~km}$ long and $80-210 \mathrm{~km}$ wide that stretches from the Julian Alps along the border between Italy and Slovenia, passes through the Croatian coast and islands, western and southern Bosnia and Herzegovina, and ends in south eastern Montenegro and north western Albania (Tišljar et al., 2002). Mt. Biokovo is closest to the Adriatic Sea (Fig. 1) and as a consequence there are areas on the mountain with continental, montane or Mediterranean climates and vegetation. Certain habitat characteristics of Mt. Biokovo cannot be found elsewhere in the Dinaric karst. To protect these features, the habitat diversity and species listed in the Habitats Directive 92/43/EEC annexes (European Comission, 1992; State Institute for Nature Protection, 2008), Biokovo was declared a Nature Park in 1981 and proposed as a NATURA 2000 site in 2010.

This study determines the influence of altitude and topographic aspect on the distribution and biogeographic characteristics of butterflies on Mt. Biokovo. It also compares the composition and biogeographic characteristics of the species on Mt. Biokovo with those on several other Dinaric karst mountains (Sket, 1994): Mt. Velebit (Croatia) (Mihoci et al., 2007), Mt. Durmitor (Montenegro) (Sijarić et al., 1984), Mt. Učka (Croatia) (Rebel, 1910; Kučinić, 2010) and the complex of Mt. Čvrsnica and Vran (Bosnia and Herzegovina) (Sijarić, 1996; Kučinić et al., 2005). Since similar faunistic research has been done on neighbouring karst areas in the Balkans it was possible 

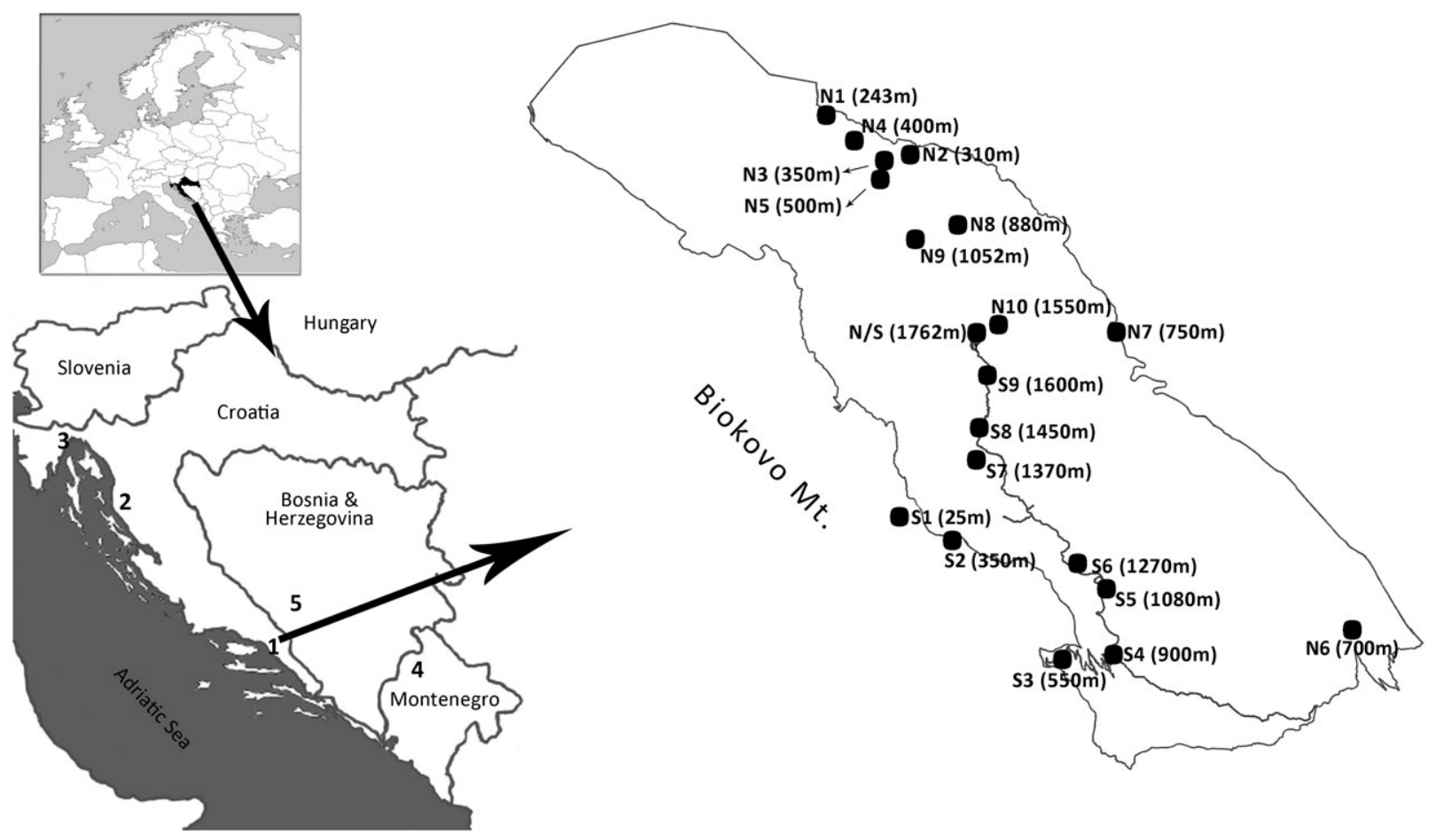

Fig. 1. Study area on Mt. Biokovo, Croatia, with sampling sites per altitude on the northern (N) and southern (S) aspects and positions of neighbouring mountains (1 - Mt. Biokovo, 2 - Mt. Velebit, 3 - Mt. Učka, 4 - Mt. Durmitor, 5 - Mt. Čvrsnica - Vran complex).

to carry out a cluster analysis of the results of these and our study on Biokovo.

\section{MATERIAL AND METHODS}

\section{Study sites}

Mt. Biokovo is $36 \mathrm{~km}$ long and $9.5 \mathrm{~km}$ wide (Fig. 1). It has an oblong shape and is orientated along a northwest-southeast axis. The highest peaks are in the southeast of the range, with the tallest Saint Jure peaking at an altitude of $1762 \mathrm{~m}$ (Kušan, 1969). Mt. Biokovo is isolated from other mountain areas in the Dinarids, as it adjoins the Adriatic Sea to the south and is separated from the nearby mountains in Croatia and Bosnia and Herzegovina by a broad lowland plain in the north.

Geomorphologic features of Mt. Biokovo originated during the karstification process in fluvial periods. Bedrock originated from sedimentation, and the main geomorphologic characteristics are due to limestone and dolomite karst, and the occasional water regime (Kušan, 1969; Telbisz et al., 2009). The aspect of the sea-facing side of the mountain is much steeper than that of the mainland side. In mid-range altitudes between 400 and 1100 meters, the sea-facing aspect is composed predominantly of cliffs and steep rocks, features which are absent on the mainland side of the mountain.

The vegetation on Mt. Biokovo includes both older Mediterranean and newer Boreal and European forms, together with different types of xerophytic, mesophytic and submontane vegetation, in which Mediterranean elements dominate. Its geographical isolation has made Mt. Biokovo a hotspot of plant endemism, with over 30 endemics (Šolić, 1983).

\section{Butterfly recording}

Butterflies were recorded by standard methods using an entomological net in all the vegetation periods from 1994 to 2004 at 10 sites on the mainland side (northeast aspect) and 9 on the coastal side (southwest aspect) and at the top of St. Jure (N/S)
(Fig. 1). The sites sampled at the different altitudes were determined exclusively by the presence of meadow/grassland, especially on the forested northern aspect. In several analyses, localities from the northern $(\mathrm{N})$ and southern $(\mathrm{S})$ aspects were grouped into three altitude zones (Z) (zone 1, NZ1 \& SZ1: 0-500 m; zone 2, NZ2 \& SZ2: 500-1000 m; zone 3, NZ3 \& SZ3: above $1000 \mathrm{~m}$ ). The same amount of time was spent sampling all the sites visited on five occasions between April and September, but in different years: the southern aspect was visited between 1994 and 2000 and the northern aspect between 2000 and 2004. Sampling at each site was done over a 1-h period, and all butterflies seen and captured in that time were recorded. Butterflies were recorded only on dry, sunny and warm days between 10 a.m. and 5 p.m. (Pollard \& Yates, 1993).

\section{Data processing}

All the tests below were computed separately for altitude and aspect. The number of species at each locality and the mean altitude for each species were determined on both the northern and southern aspects. Change of species richness with altitude and aspect was demonstrated by a regression-based test. Alpha diversity was calculated using the Shannon-Wiener diversity index $(H)$ and the Simpson diversity index $(D)$. The ShannonWiener index is more sensitive to rare species, but its numerical value is less meaningful than some other indices. In contrast, the Simpson index is relatively insensitive to rare species, making it relatively stable with respect to sample size. It can be used to count infinite and finite populations, as well as binary variables (Whittaker, 1972).

Species turnover rate was determined according to Schoener (1986) and statistical significance demonstrated by a regressionbased test.

Faunistic similarity between mountain aspects and altitude zones were calculated using the Sørensen similarity index $(S)$ (Sørensen, 1948). 
TABLE 1. Total number of species (TSN), average number of species recorded at the sample sites (ASN) on the northern and southern aspects and the Shannon's $(H)$ and Simpson's $(D)$ diversity indices for the northern and southern aspect of Mt. Biokovo.

\begin{tabular}{lcccc}
\hline Aspect & TSN & ASN & H & D \\
\hline Northern & 88 & 18.4 & 2.662 & 0.9118 \\
Southern & 80 & 17.2 & 2.442 & 0.8176 \\
\hline
\end{tabular}

Indicator species analysis (ISA) (Dufrêne \& Legendre, 1997) was used to determine which species are characteristic of aspects or zones (in two groups). Statistical significance of the indicator values $(I V s)$ obtained was tested using a permutation test with 1000 random permutations.

The effect of altitude or aspect on species composition was tested using variance decomposition with score files obtained through simple, between- and within-groups normalized principal component analysis (PCA) (Dolédec \& Chessel, 1991). In addition, three generalized linear models (GLM) (McCullagh \& Nelder, 1989; Lepš \& Šmilauer, 2003) relating species number per site (SNS) to altitude; aspect and the altitude-aspect interaction were computed using a Poisson log model.

Butterflies were categorized biogeographically according to Varga (1975, 1977, 2003a), Sijarić et al. (1984) and Schaider \& Jakšić (1989). The categories of Sijarić et al. (1984) and Schaider \& Jakšić (1989) were developed specifically for the Dinaric karst area. The percentage of each category was calculated for each altitude zone and aspect for Mt. Biokovo and overall for Mt. Velebit and Mt. Durmitor. The following biogeographical categories were used: CP - Circum-Palearctic, WP West-Palearctic, NPM - North and Pontic-Mediterranean, PCTSS - Pontic-Caspic-Turkestanic-Southsibiric, SI - Sibiric, OT - Oreo-Tundral, EA - Euro-Alpine, PMO - PonticMediterranean Oreal, XM - Xeromontane, HM - HoloMediterranean, AM - Atlantic-Mediterranean, PT - Paleotropic, PAM - Pontic-Atlantic-Mediterranean, NP - Non-Paleartic and SMR - S-Mediterranean Refugia. For all taxa, the categorization of the nominal species was used.

Butterfly diversity was compared using the Bray-Curtis distance for samples collected at five sites: Mt. Biokovo, Mt. Učka, Mt. Velebit, Mt. Durmitor and the complex of Mt. Čvrsnica and Vran.

Statistical analyses and ISA were conducted using PCOrd-4.37 and PRIMER6 software, whereas inertia decomposition and PCA were conducted using ADE-4 software (Chessel et al., 1998).

\section{RESULTS}

A total of 102 species were recorded (Appendix). The most interesting records were the endemic Zerynthia cerisy dalmacijae and Proterebia afra dalmata, and rare Papilio alexanor, all strictly protected taxa in Croatia (Ministry of Culture of Republic of Croatia, 2009). Of the species of Erebia, which all typically occur on mountains, only Erebia melas was recorded.

Higher species richness and higher average number of species per locality (species density) were recorded on the northern than on the southern aspect ( 88 vs. $80,18.4$ vs. 17.2), but these differences are not statistically significant (t-test, $p>0.05$ ). Similarly, the Shannon $(\mathrm{H})$ and Simpson $(D)$ diversity indices were higher on the northern aspect (Table 1). Sørensen's similarity between the two aspects was relatively high $(S=78.57 \%)$, with 66 species shared
TABLE 2. Total species number (TSN), average species number recorded at sampling sites (ASN) at different altitude zones and the Shannon's $(H)$ and Simpson's $(D)$ diversity indices for the different altitude zones on Mt. Biokovo.

\begin{tabular}{lcccc}
\hline Altitude zone & TSN & ASN & $H$ & $D$ \\
\hline Zone 1 $(0-500 \mathrm{~m})$ & 79 & 19.1 & 2.570 & 0.835 \\
Zone 2 $(500-1000 \mathrm{~m})$ & 66 & 16.6 & 2.390 & 0.857 \\
Zone 3 (above $1000 \mathrm{~m})$ & 67 & 17.7 & 2.712 & 0.920 \\
\hline
\end{tabular}

by the two aspects. Of all the species observed, 22 were recorded only on the northern and 14 only on the southern aspect.

The highest number of species occurred in the lowest altitude zone, zone 1 (total 79, 19.1 per locality). Altitude zones 2 and 3 had a nearly equal number of species (Table 2). The Sørensen similarity index between NZ1 and SZ1 was $56.36 \%$, with 31 species shared by the two zones; $35.00 \%$ between NZ2 and SZ2; and 52.75\% between NZ3 and SZ3, with 24 species shared. Altitude zones 1 and 2 on the northern aspect were the most similar in species composition, with a Sørensen similarity index of $71.43 \%$ (Table 3 ).

On the northern aspect, the total number of species decreased with altitude (NZ1 - 64, NZ2 - 62, NZ3 - 35). Site analysis revealed the highest number of species $(>40$ per site) at sites N1 $(243 \mathrm{~m}), \mathrm{N} 3(350 \mathrm{~m}), \mathrm{N} 6(700 \mathrm{~m})$ and N8 (880 m) (Fig. 2). Conversely, on the southern aspect, the highest number of species (56) was recorded in SZ3, compared to 46 in SZ1 and 18 in SZ2. Site analysis showed the highest number of species at the lowest site $\mathrm{S} 1$ (33 species), and 30 at sites S2 $(350 \mathrm{~m})$, S6 $(1270 \mathrm{~m})$ and S8 (1450 m). Species richness decreases with altitude although not linearly. Regression lines for both aspects are statistically insignificant $(\mathrm{N}: p=0.51 ; \mathrm{S}: p=0.33)$.

At the highest mean altitude on the southern aspect, 38 species were recorded, compared to 22 at the highest mean altitude on the northern aspect (Appendix).

On both aspects, species turnover rate (STR) increased with altitude (Fig. 3). The calculated rates indicate that a $95 \%$ change in species composition is reached at $1052-1550 \mathrm{~m}$ on the northern aspect. On the southern aspect, the highest percentage change $(81 \%)$ is reached at $1600-1762 \mathrm{~m}$. In general, STR is lower on the southern than on the northern side of the mountain (Fig. 3). A

TABLE 3. Sørensen similarity index (\%) between altitude zones on the northern and southern aspects of Mt. Biokovo (NZ1 - 0-500 $\mathrm{m}$ on the northern aspect, NZ2 - 500-1000 $\mathrm{m}$ on the northern aspect, NZ3 - above $1000 \mathrm{~m}$ on the northern aspect, SZ1 - 0-500 $\mathrm{m}$ on the southern aspect, SZ2 - 500-1000 $\mathrm{m}$ on the southern aspect, SZ3 - above $1000 \mathrm{~m}$ on the southern aspect).

\begin{tabular}{ccccccc}
\hline $\begin{array}{c}\text { Exp./alt. } \\
\text { zone }\end{array}$ & NZ1 & NZ2 & NZ3 & SZ1 & SZ2 & SZ3 \\
\hline NZ1 & - & & & & & \\
NZ2 & 71.43 & - & & & & \\
NZ3 & 46.46 & 47.42 & - & & & \\
SZ1 & 56.36 & 55.56 & 44.44 & - & & \\
SZ2 & 31.71 & 35.00 & 26.42 & 40.63 & - & \\
SZ3 & 56.67 & 67.80 & 52.75 & 49.02 & 29.73 & - \\
\hline
\end{tabular}




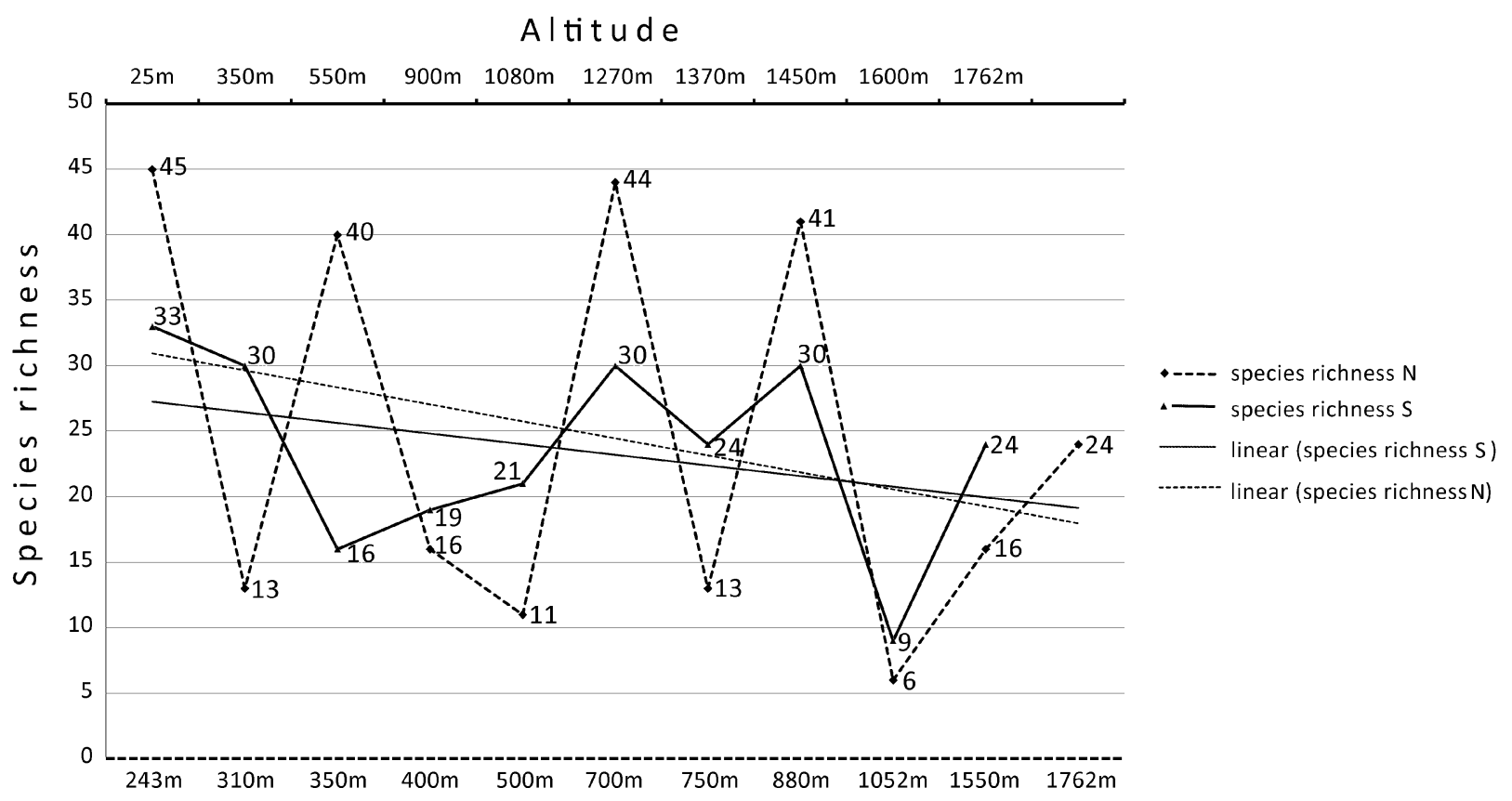

Fig. 2. The species richness at different altitudes on the northern $(\mathrm{N}-$ dashed line $)$ and southern $(\mathrm{S}-$ solid line $)$ aspects.

regression-based test showed statistical significance for STR on the northern $(\mathrm{y}=0.022 \mathrm{x}+0.72)(p<0.001)$ and insignificance on the southern side $(\mathrm{y}=-0.0002 \mathrm{x}+$ $0.759)(p>0.05)$. Aspects when combined are highly statistically different (t-test, $p<0.001$ ) (Fig. 4a, b).

ISA confirmed Argynnis niobe $(I V=33.3, P=0.042)$ and Proterebia afra dalmata $(I V=33.3, P=0.040)$ as indicator species for the northern and Hyponephele lycaon $(I V=33.3, P=0.024)$ and Chazara briseis $(I V=$ $41.7, P=0.010)$ for the southern aspect. Pieris rapae (IV $=40.0, P=0.026)$ is an indicator species of low altitudes and Polyommatus amandus $(I V=56.1, P=0.004)$, Satyrium spini $(I V=45.4, P=0.012)$, Erebia melas $(I V=$ 44.4, $P=0.016)$ and Hyponephele lycaon $(I V=44.4, P=$ 0.013 ) of high altitudes. ISA revealed no indicator species for the mid-altitudes.

Variance decomposition analysis showed that the effect of altitude on the variability in the species composition of

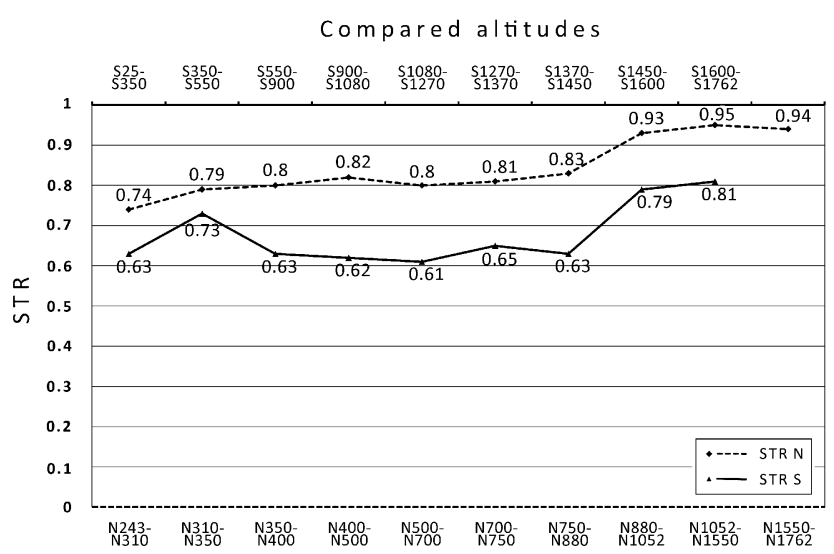

Fig. 3. Species turnover rate (STR) between different and increasing altitudes on the northern $(\mathrm{N}-$ dashed line $)$ and southern ( $\mathrm{S}-$ solid line) aspects. butterflies is 2 -fold greater than the effect of aspect (Table 4).

The General Linear Modelling (GLM) analysis using the model comparing species number per site SNS (predicted vs. observed) with altitude showed that sites S3, N4, N5 and N9 have lower species richness than predicted (below confidence limits), while sites S6, S8, N1 and N8 have higher richness than predicted (Fig. 5a). In the model comparing SNS with aspect, sites N1, N8 and $\mathrm{S} 2$ have higher species richness than predicted (Fig. 5b). In the model comparing SNS with the altitude-aspect interaction, sites S3, S9, N4, N5 and N9 have lower species richness than predicted, while sites N1, N8, S2, S6, and $\mathrm{S} 8$ have higher richness than predicted (Fig. $5 \mathrm{c}$ ).

\section{Biogeography}

On the southern aspect most of the species were Circum-Palearctic (36.25\%) followed by West-Palearctic and North and Pontic-Mediterranean species $(21.25 \%$ and $20 \%$ ). Circum-Palearctic species $(43.18 \%)$ and PonticMediterranean Oreal species $(7.95 \%)$ prevailed on the northern aspect, while North and Pontic-Mediterranean $(20 \%)$ and West-Palearctic (21.25\%) species were predominant on the southern aspect (Table 5).

With increasing altitude, the proportion of PonticMediterranean Oreal, Holo-Mediterranean, AtlanticMediterranean and Paleotropic species decreased, whereas the proportion of Circum-Palaearctic and Pontic-

TABLE 4. Inertia decomposition analysis - used to test the prominence of altitude or aspect effect on variability in species composition.

\begin{tabular}{lccc}
\hline & $\begin{array}{c}\text { Between groups } \\
\text { inertia }\end{array}$ & $\begin{array}{c}\text { Within groups } \\
\text { inertia }\end{array}$ & Total inertia \\
\hline Aspect & 0.74 & 11.23 & 13.07 \\
Altitude & 1.31 & 11.76 & 13.07 \\
\hline
\end{tabular}


A

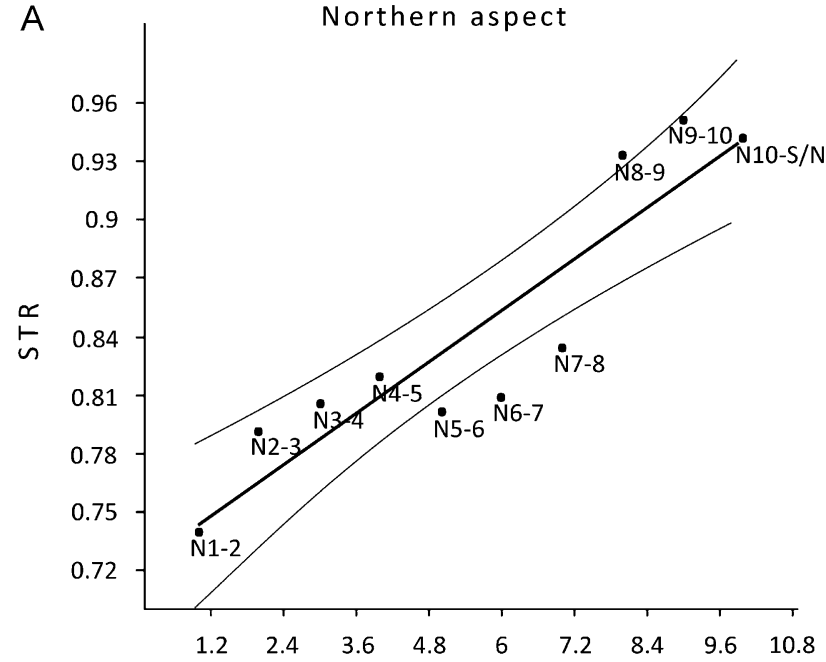

B

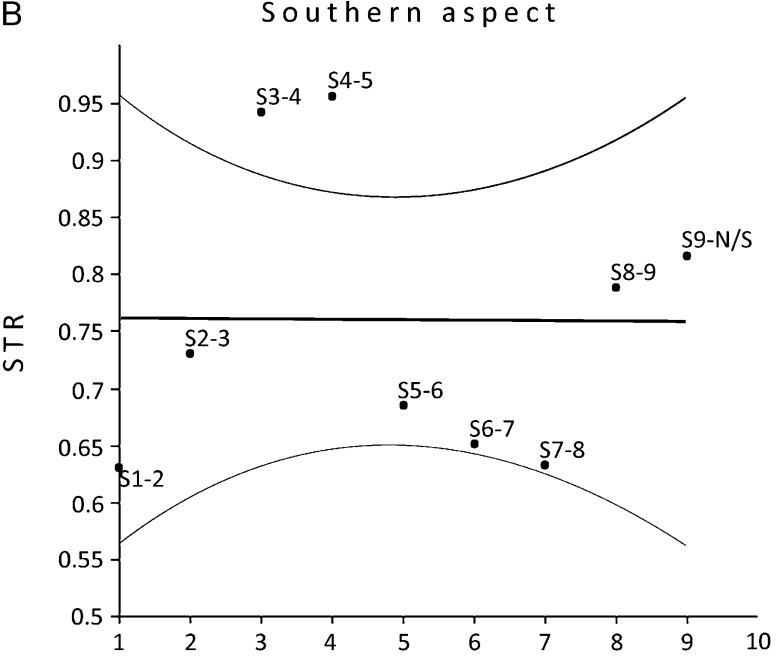

Fig. 4. Linear regression of the species turnover rate (STR). A - northern aspect; B - southern aspect.

Caspic-Turkestanic-Southsibiric species increased (Table 5).

Comparison of biogeographic proportions of species from Mt. Biokovo, Mt. Velebit (Croatia) and Mt. Durmitor (Montenegro) revealed that Circum-Palearctic species accounted for the highest share of species $(<35 \%)$, while the proportion of North and Pontic-Mediterranean and Pontic-Mediterranean Oreal species was higher on

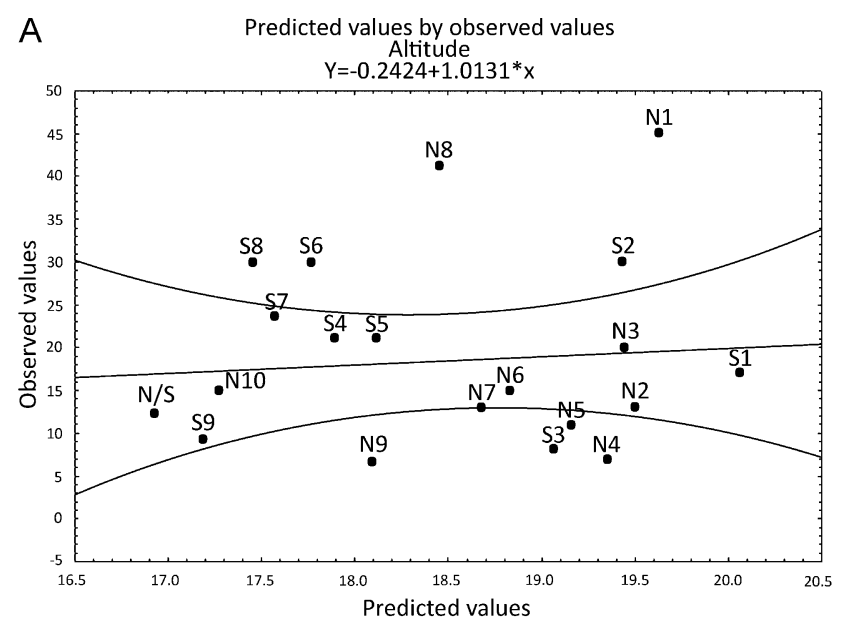

B Predicted values by observed values

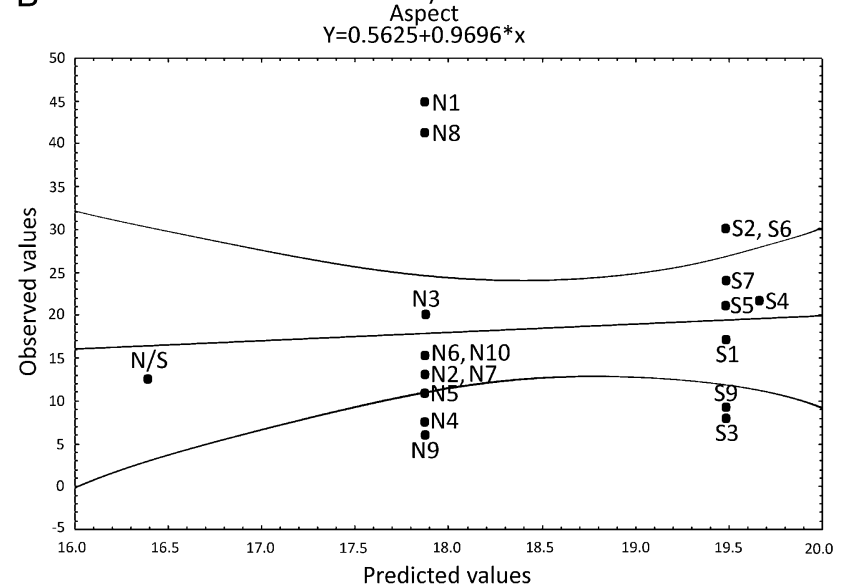

Mt. Biokovo than on Mt. Velebit or Mt. Durmitor. The share of Sibiric species was several times higher on Mt. Velebit and Mt. Durmitor than on Mt. Biokovo. No EuroAlpine species were recorded on Mt. Biokovo, in contrast to the other two mountains (Table 6).

The cluster analysis grouped Mt. Velebit and Mt. Durmitor (78\% similarity) and Mt. Biokovo and Mt. Učka (68\%). Based on butterfly diversity, the complex on Mt. Čvrsnica and Vran is more similar to Mt. Velebit and Mt. Durmitor than to that on Mt. Biokovo or Mt. Učka (Fig. 6).

\section{DISCUSSION AND CONCLUSIONS}

The position of Mt. Biokovo on the Adriatic Sea coast, at the border between the continental and Mediterranean climate, as well as its isolation from surrounding mountains, has resulted in a high degree of endemism (Šolić, 1983) and great diversity of habitats (Kušan, 1969). The

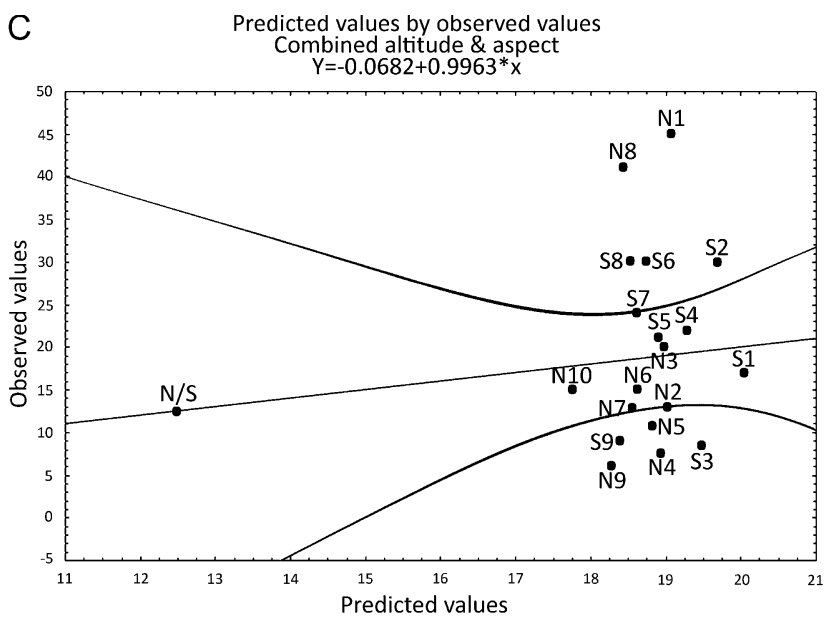

Fig. 5. The GLM analysis. A - model comparing observed with predicted species number at sites at different altitudes on the mountain; B - model comparing observed and predicted number of species at sites on the northern and southern aspects of the mountain; $\mathrm{C}$ - model comparing observed and predicted numbers of species at sites with altitude-aspect combined. 
TABLE 5. Number and proportion of species in each biogeographic group in altitude zones and on the northern and southern aspects of Mt. Biokovo (CP - Circum-Paleartic, WP - West-Palearctic, NPM - North and Pontic-Mediterranean, PCTSS - PonticCaspic-Turkestanic-Southsibiric, SI - Sibiric, PMO - Pontic-Mediterranean Oreal, HM - Holo-Mediterranean, AM - AtlanticMediterranean, PT - Paleotropic, PAM - Pontic-Atlantic-Mediterranean and NP - Non-Paleartic; Alt. zone 1-0-500 m, Alt. zone 2 - 500-1000 m, Alt. zone 3 - above 1000 m, N - north-eastern aspect, S - south-western aspect) (Varga, 1975, 1977; Sijarić et al., 1984; Schaider \& Jakšić, 1989; Varga, 2003a).

\begin{tabular}{cccccc}
\hline $\begin{array}{c}\text { Biogeographic } \\
\text { qualification }\end{array}$ & Alt. zone 1 & Alt. zone 2 & Alt. zone 3 & N & S \\
\hline CP & $32(40.50)$ & $27(40.91)$ & $28(41.79)$ & $38(43.18)$ & $29(36.25)$ \\
WP & $14(17.72)$ & $13(19.70)$ & $13(19.40)$ & $16(18.18)$ & $17(21.25)$ \\
NPM & $16(20.25)$ & $9(13.63)$ & $12(17,91)$ & $13(14.77)$ & $16(20.00)$ \\
PCTSS & $3(3.80)$ & $3(4.55)$ & $4(5.97)$ & $5(5.68)$ & $4(5.00)$ \\
SI & $1(1.27)$ & $1(1.52)$ & $1(1.49)$ & $2(2.27)$ & $1(1.25)$ \\
PMO & $5(6.33)$ & $6(9.09)$ & $3(4.48)$ & $7(7.95)$ & $4(5.00)$ \\
HM & $2(2.53)$ & $1(1.52)$ & $1(1.49)$ & $2(2.27)$ & $1(1.25)$ \\
AM & $2(2.53)$ & $1(1.52)$ & $1(1.49)$ & $1(1.14)$ & $2(2.50)$ \\
PT & $2(2.53)$ & $1(1.52)$ & $1(1.49)$ & $1(1.14)$ & $2(2.50)$ \\
PAM & $1(1.27)$ & $3(4.55)$ & $2(2.99)$ & $2(2.27)$ & $3(3.75)$ \\
NP & $1(1.27)$ & $1(1.52)$ & $1(1.49)$ & $1(1.14)$ & $1(1.25)$ \\
\hline Total & $79(100.00)$ & $66(100.00)$ & $67(100.00)$ & $88(100.00)$ & $80(100.00)$ \\
\hline
\end{tabular}

present study indicates that $53 \%$ of the Croatian butterfly fauna occurs on Mt. Biokovo (e.g. Lorković, 1989; Mihoci et al., 2005, 2006; Perković, 2006; Mihoci \& Šašić, 2009; Polak, 2009). The butterfly fauna on the southern and northern slopes is similar, probably because species ranges overlap $(\mathrm{S}=78.57 \%)$ as the northern and southern localities are relatively close together. On the other hand, the Sørensen index indicated differences in

TABLE 6. Proportion of species in each biogeographic group on Mt. Biokovo, Mt. Velebit and Mt. Durmitor (CP - CircumPaleartic, WP - West-Palearctic, NPM - North and PonticMediterranean, PCTSS - Pontic-Caspic-Turkestanic-Southsibiric, SI - Sibiric, OT - Oreo-Tundral, EA Euro-Alpine, PMO - Pontic-Mediterranean Oreal, XM Xeromontane, HM - Holo-Mediterranean, AM - AtlanticMediterranean, PT - Paleotropic, PAM - Pontic-AtlanticMediterranean, NP - Non-Paleartic and SMR - S-Mediterranean Refugia) (Varga, 1975, 1977; Sijarić et al., 1984; Schaider \& Jakšić, 1989; Varga, 2003a).

\begin{tabular}{cccc}
\hline $\begin{array}{c}\text { Biogeo- } \\
\text { graphic } \\
\text { qualification }\end{array}$ & $\begin{array}{c}\text { MT. BIOKOVO.species / bio- } \\
\text { geo. percentage }\end{array}$ & $\begin{array}{c}\text { MT. VELEBIT } \\
\text { No.species / } \\
\text { biogeo. per- } \\
\text { centage }\end{array}$ & $\begin{array}{c}\text { MT. DUR- } \\
\text { MITOR } \\
\text { No.species / bio- } \\
\text { geo. percentage }\end{array}$ \\
\hline CP & $38(37.25)$ & $50(36.50)$ & $49(37.69)$ \\
WP & $19(18.63)$ & $23(16.79)$ & $18(13.85)$ \\
NPM & $20(19.61)$ & $19(13.87)$ & $17(13.08)$ \\
PCTSS & $6(5.88)$ & $8(5.84)$ & $9(6.92)$ \\
SI & $2(1.96)$ & $13(9.49)$ & $14(10.77)$ \\
OT & - & - & $2(1.54)$ \\
EA & - & $6(4.38)$ & $8(6.15)$ \\
PMO & $7(6.86)$ & $6(4.38)$ & $6(4.62)$ \\
XM & - & $1(0.73)$ & $1(0.77)$ \\
HM & $2(1.96)$ & $2(1.46)$ & $1(0.77)$ \\
AM & $2(1.96)$ & $2(1.46)$ & $1(0.77)$ \\
PT & $2(1.96)$ & $2(1.46)$ & $1(0.77)$ \\
PAM & $3(2.94)$ & $3(2.19)$ & $2(1.54)$ \\
NP & $1(0.98)$ & $1(0.73)$ & $1(0.77)$ \\
SMR & - & $1(0.73)$ & - \\
\hline Total & $102(100.00)$ & $137(100.00)$ & $130(100.00)$ \\
\hline
\end{tabular}

the composition of the fauna in different altitude zones, in particular the isolation of species at mid-altitudes on the southern aspect.

Differences in butterfly composition may be explained by relief characteristics, vertical stratification of vegetation cover, habitat heterogeneity and climate. Climate, for example, is well known to affect the distribution of butterflies (Van Swaay et al., 2010). In addition, butterfly diversity is strongly associated with vegetation structure and composition (Fleishman et al., 2005), which differ significantly at different altitudes in the area studied. In particular, the differences in butterfly composition between the northern and southern aspects in the midaltitude zone probably reflect differences in geomorphology: the coastal slope is composed mainly of cliffs and steep rocks, while there are no vertical cliffs on the mainland side of the range, where forests and small isolated grasslands prevail (Kušan, 1969; Marincić et al., 1972; Lukšić, 1995; Penzar \& Penzar, 1995; Ridanović \& Šmunović, 995). For the same reasons, the similarity of the local climate and vegetation of the forested low- and mid-altitude zones on the northern aspect (Kušan, 1969;

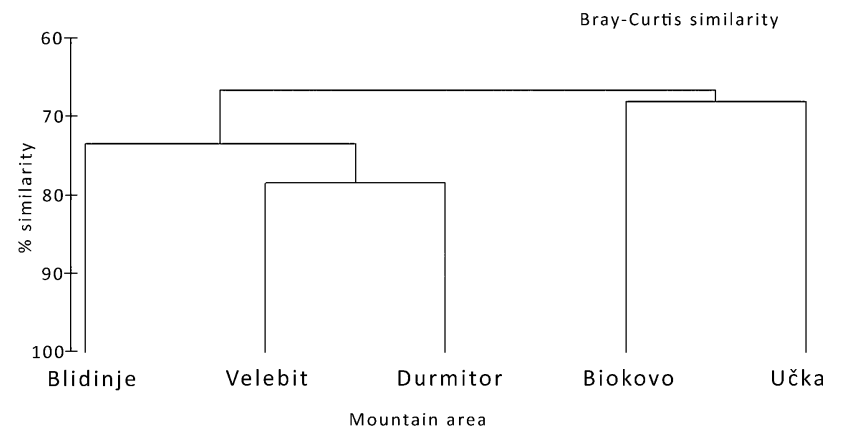

Fig. 6. Cluster analysis of butterfly species composition on Mt. Biokovo, Mt. Velebit, Mt. Učka (Croatia), Blidinje (Mt. Čvrsnica \& Vran complex) (Bosnia and Herzegovina) and Mt. Durmitor (Montenegro). 
Lukšić, 1995; Mihljević, 1995; Penzar \& Penzar, 1995) probably accounts for their nearly identical butterfly species diversity. Site analysis revealed a non-linear decrease in species richness on both aspects, which reflect nonlinear relief, non-linear change of vegetation cover and site patch areas decreasing with altitude.

On the southern aspect, more species were found at the highest mean altitude, while more species were found at the lowest mean altitude on the northern aspect. These results are expected if the vertical species distribution is a response to climatic conditions (Settele et al., 2008, Van Swaay et al., 2010), which are hotter on the southern than on the northern aspect (Kušan, 1969; Penzar \& Penzar, 1995). Therefore, some species may be highly threatened by recent climate change, such as the high-mountain species Erebia melas or Coenonympha rhodopensis. Some mountain (e.g. E. melas, C. rhodopensis) and lowland species (Zerynthia cerisyi dalmacijae, Z. polyxena, Leptotes pirithous, Lampides boeticus) were found only at high and low altitudes (Appendix).

Butterfly diversity was higher on the northern aspect due to the predominance of suitable small, calcareous, semi-natural grasslands and forest edge habitats. The richest plant and insect communities in Europe occur in calcareous grasslands (Wallis de Vries et al., 2002). The southern aspect is dominated by cliffs and rocky slopes with a scant and specific vegetation comprised mostly of chasmophytes (Kušan, 1969; Mihljević, 1995; Ridanović \& Šimunović, 1995). These habitats are less suitable for butterflies, since few of the species of plants occurring there are larval host-plants or a source of nectar for the adults. In contrast to the present study, a peak in butterfly diversity is recorded at mid-altitudes in mountain areas that do not have the specific geomorphology and climate of Mt. Biokovo (Gutiérrez, 1997; Pyrcz \& Wojtusiak, 2002). As pointed out by Hodkinson (2005), maximum species richness of terrestrial insects may occur at the highest, lowest or middle altitude, or show no trend with altitude.

The increase in species turnover rate with altitude on the southern aspect probably reflects changes in habitat structure: Aleppo pine forests at the lower altitudes gradually give way to steep chasmophytic cliffs and rocks, while the higher altitudes are rich in mountain grasslands and edge habitats associated with black pine and beech forests (e.g. Kušan, 1969). The greatest change in the fauna on the southern aspect occurred at 1600-1762 m (sites S9-S/N). Site S9 is located between two narrow sinkholes and is an area subject to a high anthropogenic influence (mountain hut, tourists, road vicinity). Site $\mathrm{S} / \mathrm{N}$, at the top of the mountain, features wide, open calcareous slopes rich in vegetation the composition of which is influenced by that of the vegetation on both aspects of the mountain and is least affected by human disturbance. Similarly, the highest number of species on the southern aspect occurred at S1 (33) and S2 (30), where meadows are rich in nectar plants and wellpreserved in a botanical reserve. High butterfly richness was also recorded at sites S6 and S8, which have habitat characteristics similar to those of S1 and S2, and confirmed by the GLM analysis using models relating species richness to altitude and the aspect-altitude interaction.

On the northern aspect, a 95\% change in species composition occurred at 1052-1550 m (N9-10). In fact, the change in species composition is significant, since there are several high-mountain species at site N10 and only a few at N9. The two sites also differ in terms of altitude and habitat composition: N9 is an isolated meadow surrounding several ponds, whereas N10 is a wide open grassy slope above a beech forest.

On Mt. Biokovo butterfly diversity and composition changes almost twice as much with altitude as with aspect. Numerous authors have pointed out that altitude is one factor that determines climate patterns and changes in floristic composition, both of which strongly affect species distribution (Wettstein \& Schmid, 1999; Pyrcz \& Wojtusiak, 2002; Storch et al., 2003; Eyre et al., 2005).

The present study revealed that several species, and two in particular, can be used as indicators. On the northern aspect, the endemic $P$. afra dalmata is an indicator species of mid-altitude regions with extensive semi-natural grasslands and edge habitats, rich in the larval-host plant Festuca spp. and Juniperus bushes for feeding (Mihoci \& Šašić, 2005). This taxon lacked suitable habitats at all of the sites on the southern aspect.

Erebia melas is an indicator species of the highest altitude zone. This xeromontane species is the only Erebia recorded on Mt. Biokovo and similarly on Mt. Olympus in Greece (Varga, 1975; Sijarić et al., 1984; Mladinov \& Lorković, 1985; Mihoci et al., 2007). On both mountains E. melas occupies a wide range of rocky habitats, usually up to the highest alpine levels (Varga \& Varga-Sipos, 2005). In contrast, Mt. Velebit (Croatia), the longest mountain on the Dinaric karst, has 11 of the 12 Erebia species occurring in this country (Mihoci et al., 2007). E. melas on Mt. Biokovo defines the southern edge of Erebia species distribution in Croatia (Mladinov \& Lorković, 1985; Jakšić, 1988). The absence of other Erebia species on Mt. Biokovo is attributable to the limited presence of high-mountain meadows rich in grasses. These are replaced by rocky slopes with sparse grasses and an unfavourable climate with long and intense summer droughts, high temperatures and infrequent precipitation (Kušan, 1969; Penzar \& Penzar, 1995). The "Erebia favourable" habitat occurs on Mt. Velebit where there are 11 species of Erebia and on Mt. Durmitor in Montenegro where there are 12 species. These mountains have a favourable climate and widespread alpine and subalpine meadows and semi-natural grass-covered slopes (Sijarić et al., 1984; Forenbacher, 2001; Nikolić, 2004).

The composition of the fauna revealed by biogeographic analysis was expected to reflect the geographical position, climate and ecological characteristics of Mt. Biokovo (Kušan, 1969; Penzar \& Penzar, 1995). As expected West-Palearctic, North and Pontic-Mediterranean, Atlantic-Mediterranean and Paleotropic species were predominant on the southern aspect of the mountain, which experiences a Mediterranean climate. On the 
northern aspect, in contrast, Circum-Paleartic, PonticCaspic-Turkestanic-Southsibiric, Sibiric and Pontic-Mediterranean Oreal species are predominant. The finding that Mt. Biokovo has a more similar fauna to Mt. Učka $(68 \%)$ than to other Dinarid mountains demonstrates the influence of the Adriatic Sea, which results in a Mediterranean climate on the coastal slopes and a continental one on mainland slopes. Both Mt. Biokovo and Mt. Učka lack high-mountain species, such as Coenonympha gardetta Prunner, Lycaena candens Herrich-Schaffer, Polyommatus eros Ochsenheimer, Polyommatus pyrenaicus Boisduval and Erebia spp. (Mann, 1869; Rebel, 1910; Stauder, 1923; Sijarić, 1991a, b; Kučinić, 2010) unlike Mt. Velebit, Mt. Durmitor or the complex of Mt. Čvrsnica and Vran (e.g. Sijarić et al., 1984; Sijarić, 1996; Kučinić et al., 2005; Mihoci et al., 2007). These findings are consistent with those of Varga \& Schmitt (2008), who found fewer alpine and arctic-alpine butterflies in the north western Dinarids than in the longer and higher mountains of northern Albania, Montenegro (Mt. Durmitor), Macedonia and western Bulgaria.

Comparison of the biogeographic characteristics of Mt. Biokovo, Mt. Velebit and Mt. Durmitor suggests that altitude and the continental and alpine climate accounts for the great similarity in composition of species of butterfly on Mt. Velebit and Mt. Durmitor $(78 \%)$. The greater influence of continental and alpine climate depends on the geographical position and greater heights of $\mathrm{Mt}$. Velebit and Mt. Durmitor compared to Mt. Biokovo (Sijarić et al., 1984; Forenbacher, 2001).

The most common species on all three mountains are Circum-Palearctic species, which is consistent with their dominance in the European fauna (Varga, 1977). However, there is a several-fold lower number of Sibiric species on Mt. Biokovo than on Mt. Velebit and Mt. Durmitor. Even more interestingly, there are no EuroAlpine species on Mt. Biokovo whereas there are eight on Durmitor. These differences in biogeographical proportions clearly reflect differences in the geographical positions, altitude and habitat characteristics of the mountains.

In conclusion, the present study indicates that the composition and biogeographic features of butterfly species can vary significantly, even over a small area such as the southern and northern aspects of one mountain. This variation reflects the diversity of habitats and the changes in climate and geomorphology with altitude and aspect.

ACKNOWLEDGEMENTS. This research was funded by the Croatian Ministry of Science, Education and Sports in the form of grants: Project No. 183-1193080-0831 to N. Tvrtković and 119-1193080-1206 to M. Kučinić.

\section{REFERENCES}

Beneš J., Kuras T. \& KonviČKA M. 2000: Assemblages of mountainous day-active Lepidoptera in the Hrubý Jeseník Mts., Czech Republic. Biologia 55: 159-167.

Chessel D., Thioulouse J. \& Dolédec S. 1998: ADE-4. Multivariate Analyses and Graphical Display for Environmental Data. User's Manual. ESA CNRS 5023, Ecologie des Eaux Douces et des Grands Fleuves, Université Lyon I, France.
Dolédec S. \& Chessel D. 1991: Recent developments in linear ordination methods for environmental sciences. Adv. Ecol. 1: $133-155$.

DufrênE M. \& LegEndre P. 1997: Species assemblages and indicator species: the need for a flexible asymmetrical approach. Ecol. Monogr. 61: 53-73.

European Commission 1992: Council Directive 92/43/EEC of 21 May 1992 on the Conservation of Natural Habitats and of Wild Fauna and Flora. (OJ L206, 22.vii.1992, p. 7), last amended 23.ix.2003 (L236, pp. 33). Council of Europe, Strasbourg, $66 \mathrm{pp}$.

Eyre M.D., Rushton S.P., Luff M.L. \& Telfer M.G. 2005: Investigating the relationships between the distribution of British ground beetle species (Coleoptera, Carabidae) and temperature, precipitation and altitude. J. Biogeogr. 32: 973-983.

Fleishman E., Austin G.T. \& Weiss A.D. 1998: An empirical test of Rapoport's rule: elevational gradients in montane butterfly communities. Ecology 79: 2482-2493.

Fleishman E., Bertusand C.J. \& Blair R.B. 2003: Effects of spatial scale and taxonomic group on partitioning of butterfly and bird diversity in the Great Basin. USA. Landsc. Ecol. 18: 675-685.

Fleishman E., Mac Nally R. \& Murphy D.D. 2005: Relationships among non-native plants, diversity of plants and butterflies, and adequacy of spatial sampling. Biol. J. Linn. Soc. 85 : 157-166.

FORENBACHER S. 2001: Velebits' Mountain Flora and Vegetation. Školska knjiga, Zagreb, 800 pp. [in Croatian].

GuTIÉRREZ D. 1997: Importance of historical factors on species richness and composition of butterfly assemblages (Lepidoptera: Rhopalocera) in a northern Iberian mountain range. $J$. Biogeogr. 24: 77-88.

Haslett J.R. 1997a: Insect communities and the spatial complexity of mountain habitats. Global Ecol. Biogeogr. 6: 49-56.

Haslett J.R. 1997b: Mountain ecology: organism responses to environmental change. An introduction. Global Ecol. Biogeogr. 6: 3-6.

HoDKINSON I.D. 2005: Terrestrial insects along elevation gradients: species and community responses to altitude. Biol. Rev. 80: 489-513.

JAKŠIĆ P. 1988: Provisional Distribution Maps of the Butterflies of Yugoslavia (Lepidoptera, Rhopalocera). Societas entomologica Yugoslavica, Zagreb, 215 pp. [in Croatian].

Karsholt O. \& RazowsKi J. 1996: The Lepidoptera of Europe. A Distributional Checklist. Apollo Books, Stenstrup, 380 pp.

Kristensen N.P., Scoble M.J. \& Karsholt O. 2007: Lepidoptera phylogeny and systematics: the state of inventorying moth and butterfly diversity. Zootaxa 1668: 699-747.

KučInIĆ M. 2010: Diversity of Butterflies of Mt. Učka Nature Park - Report. University of Zagreb, Faculty of Science, Zagreb, 64 pp. [in Croatian].

Kučinić M., Stanić S., Durbešić P., Mihoci I., Landeka N. \& DELIĆ A. 2005: A review of research into butterflies (Lepidoptera: Rhopalocera) in Blidinje nature park (Bosnia and Herzegovina). Entomol. Croat. 9: 11-28.

KudRna O. 1986: Butterflies of Europe. Aspects of the Conservation of Butterflies in Europe. AULA, Weisbaden, 323 pp.

KUŠAN F. 1969: Flora and vegetation of the Biokovo Mountain. Acta Biokov. 5(37): 6-224 [in Croatian].

LEPŠ J. \& ŠMILAUER P. 2003: Multivariate Analysis of Ecological Data Using CANOCO. Cambridge University Press, Cambridge, $267 \mathrm{pp}$. 
LIŠKA J. \& SkYVA J. 1997: Historical and recent occurrence of Lepidoptera in mountain sites of the Giant Mountains (Czech Republic). Biologia 52: 163-165.

LoRKović Z. 1989: Butterfly fauna of Croatia. In Miloševic B. (ed.): Entomofauna Hrvatske 89. Hrvatsko Entomološko Društvo, Zagreb, pp. 5-7 [in Croatian].

LUKŠIĆ I. 1995: Area of less intense bora wind at the Biokovo Mountain foot. Acta Biokov. 7: 141-147.

MANN J. 1869: Lepidoptern gesammelt während dreier Reisen nach Dalmatien in den Jahren 1850, 1862 und 1868. Verh. K. K. Zool.-Bot. Ges. Wien 19: 371-388.

MarinČIĆ S., MAGAŠ N. \& BenČEK Đ. 1972: Geological Map 1:100000. K33-35 - Ploče. Institut za geološka istraživanja, Zagreb, 52 pp. [in Croatian].

McCullagh P. \& Nelder J.A. 1989: Generalized Linear Models, 2nd ed. Chapman \& Hill, London, $511 \mathrm{pp}$.

MiHLJEvić D. 1995: Geomorphological properties of the Biokovo seaward mountain range. Acta Biokov. 7: 29-40.

Miнoci I. \& ŠAšıć M. 2005: New findings of the butterfly Dalmatian Ringlet Proterebia afra dalmata (Godart [1824]) (Lepidoptera. Satyrinae) in Croatia. Nat. Croat. 14: 121-129.

MiносI I. \& ŠAŠIĆ M. 2009: Occurrence of the satyrine butterfly Lasiommata petropolitana (Fabricius, 1787) confirmed in Croatia. Nat. Croat. 18: 175-180.

Mihoci I., TVRTKović N. \& Šs Lycaena ottomanus (Lefebvre, 1830) (Lepidoptera. Lycaenidae) - new species in the Croatian butterfly fauna. Nat. Croat. 14: $255-262$.

Minoci I., VAJdić M. \& ŠAšić M. 2006: The status of the Damon Blue Polyommatus (Agrodiaetus) damon (Denis and Schiffermüller, 1775) (Papilionoidea: Lycaenidae, Polyommatini) in the Croatian butterfly fauna. Nat. Croat. 15: 15-25.

MiносI I., ŠAŠIĆ M. \& VuKoviĆ M. 2007: Contribution to the butterfly fauna (Hesperioidea \& Papilionoidea) of the Velebit Mountain, Croatia. Nat. Croat. 16: 29-62.

Mladinov L. \& LoRKović Z. 1985: Distribution of mountain Macrolepidoptera in Croatian fauna, Jugoslavija. Acta Entomol. Jugoslav. 21: 17-36 [in Croatian].

Nikolić T. 2004: Flora Croatica Database. Department of Biology. Faculty of Science. University of Zagreb. http://hirc. botanic.hr/fcd/ (accessed 10.x.2010).

Ministry of Culture of Republic of Croatia 2009: Protocol on Proclaiming of Taxa Protected or Strictly Protected. Official Gazette No. 99/09. Narodne novine, Zagreb [in Croatian].

Penzar I. \& Penzar B. 1995: Weather and climate of the Biokovo region. Acta Biokov. 7: 115-126.

Perković D. 2006: Danaus chrysippus (Linnaeus, 1758) (Lepidoptera, Nymphalidae, Danainae), a new species in the fauna of Croatia. Nat. Croat. 15: 61-64.

PolaK S. 2009: Geranium Bronze (Cacyreus marshalli (Butler, 1898)): A new butterfly species for the Slovenian fauna. In Prešern J. (ed.): 2nd Slovenian Entomological Symposium, Book of Abstracts. Slovenian Entomological Society, Ljubljana, p. 104.

Pollard E. \& YATES T.J. 1993: Monitoring Butterflies for Ecology and Conservation. Chapman \& Hall, London, pp. 277.

Pyrcz T.W. \& Wojtusiak J. 2002: The vertical distribution of pronophiline butterflies (Nymphalidae, Satyrinae) along an elevation transect in Monte Zerpa (Cordillera de Mérida, Venezuela) with remarks on their diversity and parapatric distribution. Global Ecol. Biogeogr. 11: 211-221.

Rebel H. 1910: Lepidopteren aus dem Gebiete des Monte Maggiore in Istrien. Jahresbericht Wien. Entomol. Ver. 21: $97-110$.
Ridanović J. \& Šimunović V. 1995: Geographical characteristics and hydrographical specifity of the Biokovo area. Acta Biokov. 7: 1-11.

SCHAIDER P. \& JAKŠIĆ P. 1989: Die Tagfalter von jugoslawisch Mazedonien. Paul Schaider, München, 177 pp.

SCHOENER T.W. 1986: Pattern in terrestrial vertebrate versus arthropod communities: Do systematic differences in regularity exists? In Diamond J.M. \& Case T.J. (eds): Community Ecology. Harper \& Row, New York, pp. 556-586.

Settele J., Kudrna O., Harpke A., Kühn I., van Swahy C., Verovinik R., Warren M., Hanspach J., Hickler T., Kühn E., van Halder I., Veling K., Vliegenthart A., Wynhoff I. \& SchweIger O. 2008: Climatic Risk Atlas of European Butterflies. Pensoft, Sofia-Moscow, $712 \mathrm{pp}$.

SIJARIĆ R. 1991a: First finds of certain Rhopalocera (Lepidoptera) in Bosnia \& Herzegovina and Dalmatia. Glasn. Zemaljsk. Muz. Bosne Herceg. 30: 129-132 [in Croatian].

SIJARIĆ R. 1991b: A catalogue of the Rhopalocera (Insecta) collection of the Sarajevo donor - Boro Mihljevic. Glasn. Zemaljsk. Muz. Bosne Herceg. 30: 169-360 [in Croatian].

SIJARIĆ R. 1996: Fauna Rhopalocera (Lepidoptera) of the Vran mountain (Herzegovina). Glasn. Zemaljsk. Muz. Bosne Herceg. 31: 369-388 [in Croatian].

SiJarić R., Lorković Z., Carnelutti J. \& JaKšić P. 1984: Rhopalocera (Insecta, Lepidoptera). In Nonveiller G. (ed.): The fauna of Durmitor, Part 1. The Montenegrin Academy of Sciences and Arts, Special Editions 18, Section of Natural Sciences 11, Titograd, pp. 95-184.

Sket B. 1994: "Yugoslavia" (Bosnia-Herzegovina, Croatia, Macedonia, Montenegro, Serbia, Slovenia). In Juberthie C. \& Decu V. (eds): Encyclopaedia Biospeologica, Tome 1. Société de Biospéologie, Moulis, Bucarest, pp. 825-834.

SøRENSEN T. 1948: A method of establishing groups of equal amplitude in plant sociology based on similarity of species and its application to analyses of the vegetation on Danish commons. Biol. Skr. Dan. Vid. Sel. 5(4): 1-34.

State Institute for Nature Protection 2008: NATURA 2000 Sites in Croatia - pSCI Report. State Institute for Nature Protection, Zagreb, 384 pp. [in Croatian].

Stauder H. 1923: Die Schmetterlingsfauna der illyroadriatischen Festland- und Inselzone (Faunula IllyroAdriatica). Z. Wiss. Insektenbiol. 18: 10-18, 58-68, 106-114, 187-202, 253-267, 317-327.

Storch D., Konvicka M., Benes J., Martinkova J. \& Gaston K. J. 2003: Distribution patterns in butterflies and birds of the Czech Republic: separating effects of habitat and geographical position. J. Biogeogr. 30: 1195-1205.

Šolić M.E. 1983: Biokovo Mountain endemism. Acta Biokov. 2: 179-182.

Telbisz T., Dragušica H. \& Nagy B. 2009: Doline morphometric analysis and Karst morphology of Biokovo Mt (Croatia) based on field observations and digital terrain analysis. Hrvat. Geograf. Glas. 71(2): 5-22.

Tišljar J., Vlahović I., Velić I. \& Sokać B. 2002: Carbonate platform megafacies of the Jurassic and Cretaceous deposits of the Karst Dinarides. Geol. Croat. 55: 139-170.

Van Swaay C.A.M., Harpke A., Van Strien A., Fontaine B., Stefanescu C., Roy D., Maes D., Kühn E., Õunap E., Regan E.C., Švitra G., Heliölä J., Settele J., Musche M., Warren M.S., Plattiner M., Kuussaari M., Cornish N., Schweiger O., Feldmann R., Julliard R., Verovinik R., Roth T., Brereton T. \& Devictor V. 2010: The Impact of Climate Change on Butterfly Communities 1990-2009. Report VS2010.025, Butterfly Conservation Europe \& De Vlinderstichting, Wageningen, $22 \mathrm{pp}$. 
VARGA Z. 1975: Geographische Isolation und Subspeziation der Lepidopteren in den Hochgebirgen Balkans. Acta Entomol. Jugoslav. 11: 5-40.

VARGA Z. 1977: Das Prinzip der areal-analytischen Methode in der Zoogeographie und die Faunelemente-Einteilung der europäischen Tagschmetterlinge (Lepidoptera, Diurna). Acta Biol. Debrec. 14: 223-285.

VARGA Z. 1995: Geographical patterns of biological diversity in the Palaearctic Region and the Carpathian Basin. Acta Zool. Hung. 41: 71-92.

VARGA Z. 2003a: Post-glacial dispersal strategies of Orthoptera and Lepidoptera in Europe and in the Carpathian basin. In Reemer M., van Helsdingen P.J. \& Kleukers R.M.J.C. (eds): Changes in Ranges: Invertebrates on the Move. Proceedings of the 13th International Colloquium of the European Invertebrate Survey, Leiden, 2-5 September 2001. European Invertebrate Survey, Leiden, pp. 93-105.

VARGA Z. 2003b: The geographical distribution of the high mountain Macrolepidoptera in Europe. In Nagy L., Grabherr G., Körner C. \& Thompson D.B.A. (eds): Alpine Biodiversity in Europe, Ecological Studies 167. Springer, Berlin, Heidelberg, pp. 239-258.

VARGA Z. 2008: Mountain coniferous forests, refugia and butterflies. Mol. Ecol. 17: 2101-2106.
VARga Z.S. \& SchmitT T. 2008: Types of oreal and oreotundral disjunctions in the western Palearctic. Biol. J. Linn. Soc. 93: 415-430.

VARGA Z. \& VARGA-Sipos J. 2005: Vertical distribution of the alpine Lepidoptera in the Carpathians and in the Balkan peninsula in relation with the zonation of the vegetation. In Kühn E., Feldmann R., Thomas J. \& Settele J. (eds): Studies on the Ecology and Conservation of Butterflies in Europe. Vol. 1. General Concepts and Case Studies, Conference Proceedings UFZ Leipzig-Halle, Pensoft, Sofia-Moscow, pp. 61-64.

Wallis De Vries M.F., Poschlod P. \& Willems J.H. 2002: Challenges for the conservation of calcareous grasslands in northwestern Europe: integrating the requirements of flora and fauna. Biol. Conserv. 104: 265-273.

WetTSTeIN W. \& Schmid B. 1999: Conservation of arthropod diversity in montane wetlands: effects of altitude, habitat quality and habitat fragmentation on butterflies and grasshoppers. J. Appl. Ecol. 36: 363-373.

WHITTAKER R.H. 1972: Evolution and measurement of diversity. Taxon 21: 213-251.

Received July 19, 2010; revised and accepted June 9, 2011

ApPENDIX. List of the butterflies recorded and their occurrence in the different altitude zones on Mt. Biokovo (NZ1 - 0-500 $\mathrm{m}$ on the northern aspect, NZ2 - 500-1000 m on the northern aspect, NZ3 - above $1000 \mathrm{~m}$ on the northern aspect, SZ1 - 0-500 $\mathrm{m}$ on the southern aspect, SZ2 - 500-1000 m on the southern aspect, SZ3 - above $1000 \mathrm{~m}$ on the southern aspect), MA(N) - mean altitude of species on northern aspect, MA(S) - mean altitude of species on southern aspect, BQ - biogeographical qualification: CP - Circum-Paleartic, WP West-Palearctic, NPM - North and Pontic-Mediterranean, PCTSS - Pontic-Caspic-Turkestanic-Southsibiric, SI - Sibiric, PMO - PonticMediterranean Oreal, HM - Holo-Mediterranean, AM - Atlantic-Mediterranean, PT - Paleotropic, PAM - Pontic-Atlantic-Mediterranean and NP - Non-Paleartic. Systematics follows Karsholt \& Razowski (1996) and biogeography Varga (1975, 1977), Sijarić et al. (1984), Schaider \& Jakšić (1989) and Varga (2003a). Biogeographical categories according to Sijarić et al. (1984) and Schaider \& Jakšić (1989) are used as they are especially modified for the Dinaric karst area.

\begin{tabular}{|c|c|c|c|c|c|c|c|c|c|}
\hline Species & NZ1 & NZ2 & NZ3 & $\mathrm{SZ1}$ & $\mathrm{SZ2}$ & SZ3 & $\mathrm{MA}(\mathrm{N})$ & $\mathrm{MA}(\mathrm{S})$ & $\mathrm{BQ}$ \\
\hline Erynnis tages (L.) & - & - & + & - & - & - & 1550 & & $\mathrm{CP}$ \\
\hline Carcharodus lavatherae (Esper, 1783) & - & + & - & - & - & + & 880 & 1410 & PAM \\
\hline Carcharodus floccifera (Zeller, 1847) & - & - & - & + & - & - & & 350 & AM \\
\hline Pyrgus sidae (Esper, 1784) & + & + & - & - & - & - & 619 & & PMO \\
\hline Pyrgus armoricanus (Oberthür, 1910) & - & - & - & - & + & - & & 550 & PAM \\
\hline Pyrgus alveus (Hübner, 1803) & + & - & - & - & - & - & 350 & & $\mathrm{CP}$ \\
\hline Thymelicus lineola (Ochsenheimer, 1808) & - & + & - & - & - & - & 880 & & $\mathrm{CP}$ \\
\hline Thymelicus sylvestris (Poda, 1761) & + & + & - & - & - & + & 625 & 1467 & PAM \\
\hline Thymelicus acteon (Rottemburg, 1775) & - & + & - & - & - & + & 675 & 1450 & $\mathrm{CP}$ \\
\hline Ochlodes venata (Bremer \& Grey, 1853) & + & - & - & - & - & + & 243 & 1450 & $\mathrm{CP}$ \\
\hline Zerynthia polyxena (Denis \& Schiffermüller, 1775) & - & - & - & + & - & - & & 25 & NPM \\
\hline Zerynthia cerisy dalmacijae (Sala \& Bollino, 1994) & - & - & - & + & - & - & & 25 & NPM \\
\hline Parnassius mnemosyne (L.) & - & + & + & - & - & + & 1035 & 1450 & PCTSS \\
\hline Iphiclides podalirius (L.) & + & + & + & + & + & + & 624 & 905 & WP \\
\hline Papilio machaon L. & - & - & + & + & + & - & 1762 & 308 & $\mathrm{CP}$ \\
\hline Papilio alexanor Esper, 1800 & + & + & - & - & - & - & 512 & & PMO \\
\hline Leptidea sinapis (L.) & + & + & + & + & - & + & 415 & 925 & NPM \\
\hline Anthocharis cardamines (L.) & + & + & - & + & + & - & 527 & 308 & $\mathrm{CP}$ \\
\hline Euchloe ausonia (Hübner, 1804) & + & + & - & - & + & - & 459 & 550 & WP \\
\hline Aporia crataegi (L.) & + & + & + & - & - & + & 708 & 1450 & $\mathrm{CP}$ \\
\hline Pieris brassicae (L.) & + & + & - & + & - & + & 491 & 855 & $\mathrm{CP}$ \\
\hline Pieris mannii (Mayer, 1851) & + & + & - & + & + & + & 507 & 830 & NPM \\
\hline Pieris rapae (L.) & + & + & - & + & - & + & 442 & 187 & $\mathrm{CP}$ \\
\hline Pieris ergane (Geyer, 1828) & + & + & + & + & - & + & 785 & 1202 & NPM \\
\hline Pieris napi (L.) & + & + & - & + & - & - & 574 & 350 & $\mathrm{CP}$ \\
\hline Pontia daplidice (L.) & + & - & + & + & - & + & 1056 & 552 & $\mathrm{CP}$ \\
\hline Colias croceus (Fourcroy, 1785) & + & + & + & + & + & + & 777 & 550 & PT \\
\hline Colias hyale (L.) & - & + & - & - & - & + & 880 & 1175 & NPM \\
\hline Colias alfacariensis Ribbe, 1905 & + & + & - & - & - & + & 538 & 1270 & NPM \\
\hline Gonepteryx rhamni (L.) & + & + & + & - & - & + & 643 & 1363 & $\mathrm{CP}$ \\
\hline Gonepteryx cleopatra (L.) & + & - & - & - & - & - & 385 & & NPM \\
\hline Lycaena phleas (L.) & + & - & - & + & - & - & 243 & 25 & $\mathrm{CP}$ \\
\hline Lycaena thersamon (Esper, 1784) & - & - & - & + & - & - & & 25 & WP \\
\hline
\end{tabular}


Callophrys rubi (L.)

Satyrium w-album (Knoch, 1782)

Satyrium spini (Denis \& Schiffermüller, 1775)

Satyrium ilicis (Esper, 1779)

Satyrium acaciae (F.)

Lampides boeticus (L.)

Leptotes pirithous (L.)

Celastrina argiolus (L.)

Pseudophilotes vicrama (Moore, 1865)

Scolitantides orion (Pallas, 1771)

Glaucopsyche alexis (Poda, 1761)

Plebeius argus (L.)

Plebeius idas (L.)

Aricia agestis (Denis \& Schiffermüller, 1775)

Aricia artaxerxes (F.)

Polyommatus semiargus (Rottemburg, 1775)

Polyommatus escheri (Hübner, 1823)

Polyommatus dorylas (Denis \& Schiffermüller, 1775)

Polyommatus amandus (Schneider, 1792)

Polyommatus icarus (Rottemburg, 1775)

Polyommatus daphnis (Denis \& Schiffermüller, 1775)

Polyommatus bellargus (Rottemburg, 1775)

Polyommatus coridon (Poda, 1761)

Libythea celtis (Laicharting, 1782)

Argynnis paphia (L.)

Argynnis pandora (Denis \& Schiffermüller, 1775)

Argynnis aglaja (Linnaeus, 1758)

Argynnis adippe (Denis \& Schiffermüller, 1775)

Argynnis niobe (L.)

Issoria lathonia (L.)

Brenthis hecate (Denis \& Schiffermüller, 1775)

Boloria euphrosyne (L.)

Vanessa atalanta (L.)

Vanessa cardui (L.)

Inachis io (L.)

Aglais urticae (L.)

Polygonia egea (Cramer, 1775)

Nymphalis antiopa (L.)

Nymphalis polychloros (L.)

Nymphalis xanthomelas (Esper, 1781)

Melitaea cinxia (L.)

Melitaea trivia (Denis \& Schiffermüller, 1775)

Melitaea didyma (Esper, 1778)

Limenitis camilla $(\mathrm{L}$.

Limenitis reducta Staudinger, 1901

Neptis sappho (Pallas, 1771)

Neptis rivularis (Scopoli, 1763)

Pararge aegeria (L.)

Lasiommata megera (L.)

Lasiommata maera (L.)

Coenonympha rhodopensis Elwes, 1900

Coenonympha pamphilus (L.)

Pyronia tithonus (L.)

Pyronia cecilia (Vallantin, 1894)

Maniola jurtina (L.)

Hyponephele lycaon (Rottemburg, 1775)

Hyponephele lupinus (O. Costa, 1836)

Proterebia afra dalmata (Godart, 1824)

Erebia melas (Herbst, 1796)

Melanargia galathea $(\mathrm{L}$.

Melanargia larissa (Geyer, 1828)

Satyrus ferula (F.)

Minios dryas (Scopoli, 1763)

Hipparchia fagi (Scopoli, 1763)

Hipparchia syriaca (Staudinger, 1871)

Hipparchia semele (L.)

Hipparchia statilinus (Hufnagel, 1766)

Brintesia circe (F.)

Chazara briseis (L.)

\begin{tabular}{|c|c|c|c|c|c|c|c|c|}
\hline+ & + & - & + & - & - & 599 & 188 & CP \\
\hline+ & - & - & - & - & - & 356 & & NPM \\
\hline - & + & - & - & - & + & 880 & 1490 & WP \\
\hline+ & + & + & - & - & - & 763 & & NPM \\
\hline+ & - & - & - & - & + & 243 & 1080 & WP \\
\hline - & - & - & + & - & - & & 25 & PT \\
\hline - & - & - & + & - & - & & 25 & NPM \\
\hline+ & - & - & + & - & - & 276 & 25 & $\mathrm{CP}$ \\
\hline+ & + & - & - & - & + & 660 & 1080 & AM \\
\hline+ & + & - & + & - & - & 515 & 350 & PCTSS \\
\hline+ & - & - & - & - & - & 301 & & $\mathrm{CP}$ \\
\hline+ & - & + & - & - & + & 513 & 1762 & CP \\
\hline+ & + & - & - & - & + & 495 & 1490 & $\mathrm{CP}$ \\
\hline+ & + & + & + & + & + & 536 & 757 & CP \\
\hline+ & - & - & - & - & - & 500 & & SI \\
\hline+ & + & - & - & - & - & 562 & & CP \\
\hline - & - & + & - & - & + & 1550 & 1450 & WP \\
\hline- & - & + & - & - & + & 1550 & 1270 & NPM \\
\hline- & + & - & - & - & + & 880 & 1422 & SI \\
\hline+ & + & - & + & + & + & 536 & 915 & CP \\
\hline- & - & - & - & - & + & & 1270 & NPM \\
\hline+ & + & - & + & + & - & 558 & 485 & WP \\
\hline - & + & - & - & - & + & 750 & 1225 & NPM \\
\hline+ & + & + & + & - & - & 783 & 25 & $\mathrm{CP}$ \\
\hline+ & + & - & + & - & + & 570 & 900 & CP \\
\hline+ & + & - & + & - & + & 532 & 1110 & CP \\
\hline+ & + & - & - & - & + & 515 & 1354 & CP \\
\hline+ & + & + & - & - & + & 713 & 1270 & CP \\
\hline+ & + & + & - & - & - & 809 & & CP \\
\hline+ & + & + & + & - & + & 816 & 773 & CP \\
\hline - & + & - & - & - & + & 751 & 1270 & WP \\
\hline+ & + & + & - & - & - & 848 & & CP \\
\hline+ & - & + & + & - & + & 880 & 810 & WP \\
\hline+ & + & + & + & - & + & 917 & 1023 & NP \\
\hline - & - & + & - & - & + & 1762 & 1450 & $\mathrm{CP}$ \\
\hline - & - & + & - & - & + & 1762 & 1485 & CP \\
\hline+ & + & - & + & - & + & 562 & 774 & NPM \\
\hline - & + & + & - & - & - & 1321 & & $\mathrm{CP}$ \\
\hline+ & - & - & - & - & - & 385 & & WP \\
\hline+ & - & + & - & - & - & 897 & & PCTSS \\
\hline+ & + & - & + & + & + & 592 & 633 & $\mathrm{CP}$ \\
\hline - & + & - & - & - & - & 880 & & WP \\
\hline+ & + & + & + & - & - & 736 & 188 & CP \\
\hline+ & - & - & - & - & - & 356 & & $\mathrm{CP}$ \\
\hline+ & + & - & - & + & + & 551 & 1090 & HM \\
\hline - & - & - & - & - & + & & 1370 & PCTSS \\
\hline- & + & - & - & - & - & 880 & & PCTSS \\
\hline+ & + & - & + & - & - & 513 & 25 & WP \\
\hline+ & + & + & + & + & + & 589 & 638 & WP \\
\hline+ & + & - & + & - & + & 486 & 1025 & $\mathrm{CP}$ \\
\hline- & + & - & - & - & + & 675 & 1410 & PMO \\
\hline- & + & + & + & + & + & 906 & 849 & $\mathrm{CP}$ \\
\hline+ & - & - & - & - & - & 350 & & NPM \\
\hline- & - & - & + & - & - & & 188 & NPM \\
\hline+ & + & + & + & - & - & 901 & 188 & WP \\
\hline - & - & - & - & - & + & & 1293 & WP \\
\hline+ & + & + & - & - & + & 759 & 1175 & WP \\
\hline+ & + & - & - & - & - & 492 & & PMO \\
\hline - & - & + & - & - & + & 1762 & 1473 & PMO \\
\hline+ & + & - & - & + & + & 473 & 1220 & NPM \\
\hline+ & - & - & - & + & - & 243 & 550 & PMO \\
\hline- & + & - & + & - & + & 675 & 997 & WP \\
\hline- & - & + & + & - & + & 1762 & 860 & PCTSS \\
\hline- & - & - & + & - & + & & 1143 & NPM \\
\hline- & + & + & + & + & - & 1017 & 462 & PMO \\
\hline+ & + & + & + & - & + & 683 & 738 & WP \\
\hline- & - & - & + & - & - & & 25 & NPM \\
\hline+ & - & - & - & - & - & 300 & & HM \\
\hline - & - & - & + & + & + & & 765 & WP \\
\hline
\end{tabular}

